\title{
Detection and quantification of the air inoculum of Caliciopsis pinea in a plantation of Pinus radiata in Italy
}

\author{
Leticia Botella ${ }^{(1)}$, \\ Aneta Bačová (1), \\ Milon Dvorák ${ }^{(2)}$, \\ Tomáš Kudláček ${ }^{(1)}$, \\ Alessia L Pepori ${ }^{(3)}$, \\ Alberto Santini ${ }^{(3)}$, \\ Luisa Ghelardini ${ }^{(3)}$, \\ Nicola Luchi ${ }^{(3)}$
}

\begin{abstract}
Caliciopsis pinea has been historically described as a secondary pathogen of pines. However, it has recently been associated with severe damages on Pinus radiata in Italy. Our study focused on the description of the seasonal spore dispersal of $C$. pinea and its relation to meteorological conditions (temperature, leaf wetness, relative humidity and precipitations). For this experiment one infected $P$. radiata plantation was sampled in Tuscany (Italy). A rotating arm spore trap together with a weather station were installed to sample the aerospora for $24 \mathrm{~h}$ every week from May to November 2016. Exposed tapes from spore traps were directly analyzed after DNA extraction by qPCR using specific primers and TaqMan MGB probe. The study shows an irregular occurrence of the inoculum of $C$. pinea throughout the whole sampling period with peak levels in mid-June and early August. The statistical analysis of the DNA and climatic data clearly show the strong influence of precipitation on the spore production of this pathogen. Furthermore, the very low detection limit of the qPCR experiment shows the efficacy and suitability of rotating arm spore traps for early detection of this pathogen.
\end{abstract}

\section{Keywords: Caliciopsis Canker, Monterey Pine, Aerospora, qPCR}

and well-drained soils also contributed to its collapse (Ciancio et al. 2006).

Additionally, some pests and diseases may represent a serious threat for $P$. radiata plantations. Among them, Caliciopsis pinea Peck, an ascomycetous fungus belonging to the family Coryneliaceae and order Coryneliales (Fitzpatrick 1942). It infects pine trees of all ages mainly in sandy and well-drained soils in North America (Munck et al. 2016). In eastern USA C. pinea may affect Pinus echinata Mill, Pinus pungens Lamb, Pinus rigida Mill, Pinus virginiana Mill, Pinus taeda L. and Pinus strobus L., the white pine, which is suffering a severe damage over the last years (LaFlamme 2004, Munck et al. 2015). C. pinea has been observed in Europe on exotic pine species, such as Pinus pumila (Pall.) Regel (Rehm 1896), P. echinata, P. pungens, P. rigida, $P$. virginiana and $P$. radiata (Capretti 1978, Lu- $\square$ (1) Phytophthora Research Centre, Department of Forest Protection and Wildlife Management, Faculty of Forestry and Wood Technology, Mendel University in Brno, Zemedelská 1, 61300 Brno (Czech Republic); (2) Department of Forest Protection and Wildlife Management, Faculty of Forestry and Wood Technology, Mendel University in Brno, Zemedelská 1, 61300 Brno (Czech Republic); (3) Institute for Sustainable Plant Protection, National Research Council (IPSP-CNR), v. Madonna del Piano 10, 50019 Sesto Fiorentino, Firenze (Italy)

@ Leticia Botella (qqbotell@mendelu.cz)

Received: May 24, 2018 - Accepted: Jan 21, 2019

Citation: Botella L, Bačová A, Dvorák M, Kudláček T, Pepori L, Santini A, Ghelardini L, Luchi N (2019). Detection and quantification of the air inoculum of Caliciopsis pinea in a plantation of Pinus radiata in Italy. iForest 12: 193-198. - doi: 10.3832/ifor2866-012 [online 2019-04-10]

Communicated by: Claudia Cocozza chi et al. 2015), and on native European pines, such as, Pinus pinaster Ait., Pinus pinea L. and Pinus halepensis Mill (Lanier 1965, Delatour 1969). Particularly, in Italy, it was firstly described as causing cortical cankers in young plantations of P. pinaster and Pinus insignis Dougl. (= P. radiata D. Don) (Capretti 1978). The pathogen has been also reported on Pinus nigra Dougl. (Capretti 1980).

Symptoms caused by $C$. pinea infection include sharply delimited cankers on trunks and branches crown wilting, defoliation (Ray 1936) and a profuse resin production. Previous studies showed that the cankers did not produce significant damage (Ray 1936, Cram et al. 2009), but other authors have associated the presence of $C$. pinea with top killing cankers on trees (LaFlamme 2004). C. pinea produces small, globose, clustered, black pycnidia and stalked perithecia that arise from a stromatic cushion (McCormack 1936, Funk 1963). Blackhair-like fruiting structures persist throughout the year and spores mature in late winter and spring. Spores are disseminated by wind and rain and typically enter through bark lenticels or small insect wounds (Funk 1964, Delatour 1969).

The airborne inoculum of forest pathogens is generally underestimated in epidemiological studies. In particular, no information on C. pinea sporulation and its relationship with environmental parameters have been studied so far. However, due to the climate changes in the Mediterranean region, the pathogen sporulation and dispersal may be favored, leading to an increase of the disease incidence (Santini \& 


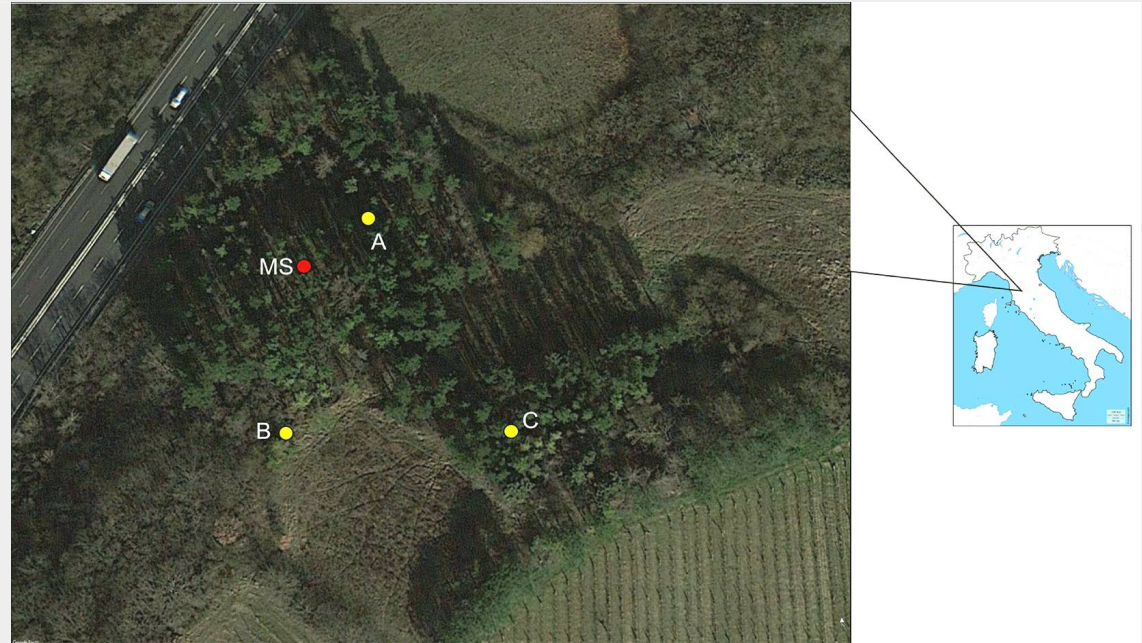

Fig. 1 - Location of the spore traps (A, B, C) and the meteo station (MS) at the sampling site in Carcheri (Tuscany, central Italy).

Ghelardini 2015). As nowadays new spore trapping tools coupled with sensitive molecular methods give the opportunity to ef-

ficiently collect and detect airborne fungal inoculum (Brittain et al. 2013), here we propose to analyze the seasonal spore disper-

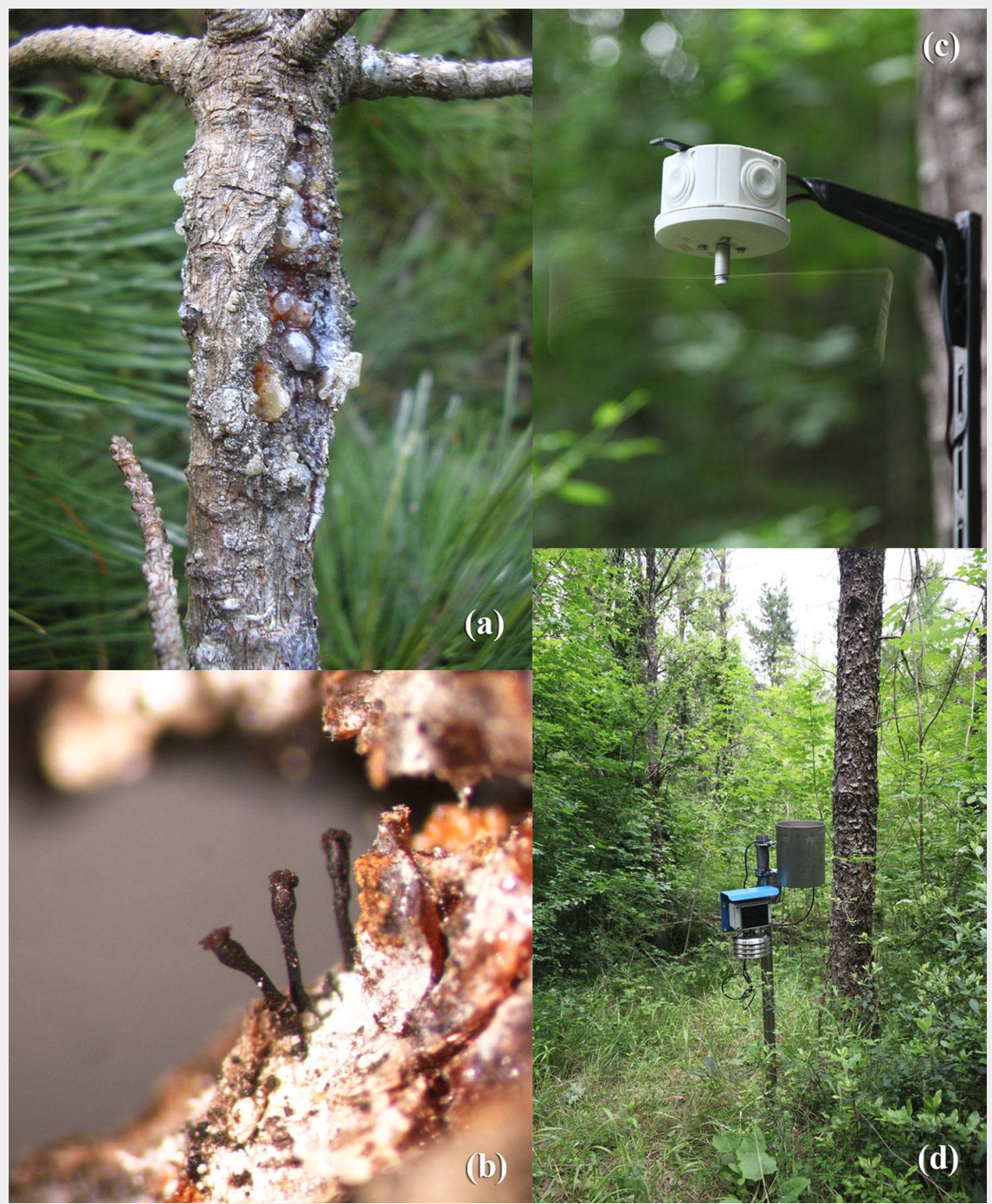

Fig. 2 - (a) Caliciopsis cankers on a P. radiata trunk; (b) Black-hair-like fruiting bodies of Caliciopsis pinea growing from a canker; (c) RAST device; (d) meteorological station. sal of C. pinea in a P. radiata plantation, and its relation to local climatic conditions by using a rotating-arm spore trapping method combined with qPCR.

\section{Materials and methods}

\section{Sampling area}

A P. radiata plantation in Carcheri (Lastra a Signa, Florence, Italy $-43.715875^{\circ} \mathrm{N}$, $11.073649^{\circ} \mathrm{E}$ ) was selected for the aim of this study. The stand is a 2-ha monospecific plantation of $P$. radiata, in a northwest facing slope (Fig. 1). The undergrowth is characterized by some Mediterranean shrub species, including some oaks (Quercus pubescens, $Q$. cerris) and other native tree species (Acer campestris, Fraxinus ornus, Rosa canina, Cornus mas, Sorbus estica, Crataegus monogyna, Equisetum sp. and Asparagus officinalis).

The plantation showed $44.7 \%$ of trees affected by Caliciopsis cankers with abundance of resin and characteristic fruit bodies from the lesion (Fig. 2a, Fig. 2b). Cankers length ranged around $1-3 \mathrm{~cm}$. The pathogen was detected by isolation on PDA (Luchi et al. 2015) and molecular techniques (Luchi et al. 2018).

\section{Spore trapping and climate data}

The rotating-arm spore traps ROTTRAP 120 (RAST - Fig. 2C) were constructed by Milon Dvorák (Boršov nad Vltavou, Czech Republic), based on the principles of Perkins \& Leighton (1957), developed by Chandelier et al. (2014) and modified by Dvorák et al. (2017). An electric motor rotates $2400 \mathrm{rpm}$ with a $0.8 \mathrm{~mm}$ thick Ushaped, square section wire. The vertical impactors of $50 \mathrm{~mm}$ in length distanced at $200 \mathrm{~mm}$ were covered for every sampling with a new double-sided non-woven tape (Tesa SE ${ }^{\oplus}$, Norderstadt, Germany). Covering the front side (according to the direction of rotation) of each impactor, the spore trap provided an impaction area of $80 \mathrm{~mm}^{2}$. RASTs were sampling the air $1.4 \mathrm{~m}$ above the ground at a speed of $120 \mathrm{~L} \mathrm{~min}^{-1}$ with almost a $100 \%$ collecting efficiency for particles bigger than $7.18 \mu \mathrm{m}$. This limiting spherical diameter of particles was calculated using equations and charts published by Noll (1970). In his paper a comprehensive theoretical and experimental testing of rotating-arm spore traps with variable parameters was reported.

The RASTs were placed in three spots ( $A$, $B$ and C - Fig. 1) of the infested forest at a distance of about $100 \mathrm{~m}$ each other. The automatic weather station (AMET, Velké Bílovice, Czech Republic) was installed next to the RAST on the spot A (Fig. 1, Fig. 2d).

The RASTs were sampling 24 consecutive hours once a week for a period of 29 continuous weeks from the May $17^{\text {th }}$ to November $29^{\text {th }}, 2016$. After each sampling period, the exposed tapes were immediately placed into 2-ml sterile microtubes and stored at $-20^{\circ} \mathrm{C}$.

The automatic weather station (Fig. $2 \mathrm{~d}$ ) 
carried out climatic measurements continuously over the course of the entire sampling period. Variables were recorded every 10 minutes and included air temperature, air relative humidity, dew point, leaf wetness and precipitations. The mean daily temperature, as well as other mean daily values, were calculated as an average of these measurements from midnight to midnight.

\section{DNA extraction from the spore trap samples}

DNA extractions included negative con trols, which were prepared as microtubes with no tape rods.

For the purpose of spore disruption, we added $0.3 \mathrm{~g}$ of $0.1 \mathrm{~mm}$ and $0.1 \mathrm{~g}$ of 0.5 $\mathrm{mm}$ balotina beads and $250 \mu \mathrm{l}$ of $0.1 \%$ Nonidet $\mathrm{P}_{40}{ }^{\oplus}$-substitute (Applichem, Darmstadt, Germany) to each tube. The disruption itself was then accomplished by a Mixer Mill $\mathrm{MM}_{400^{\oplus}}$ (Retsch, Haan, Germany) activated for $10 \mathrm{~min}$ at $30 \mathrm{~Hz}$. Then, the lysis buffer (Dvorák et al. 2015) and $4 \mu \mathrm{l}$ RNase A (E.Z.N.A. ${ }^{\oplus}$ Plant DNA kit, Omega Bio-tek, Norcross, GA, USA) were added to all samples. The mixture was incubated for $60 \mathrm{~min}$ at $65^{\circ} \mathrm{C}$ with occasional mixing. For further processing, the E.Z.N.A. Plant Mini Kit was used. The elution used $100 \mu \mathrm{l}$ of preheated buffer after 10 min of incubation at room temperature (Dvorák et al. 2015).

\section{qPCR experiments}

The primer set Cpin-F (5'-ATTGTCGTCTGA ATTCTGATGCA-3') and Cpin-R (5'-TTCATC GATGCCAGAACCAA-3') and the TaqMan ${ }^{\circledR}$ MGB probe (Cpin-Pr) (5'-VIC-AATAAAACTTT CAACAACGGATC-MGBNFQ-3') described by Luchi et al. (2018) were used to detect and quantify $C$. pinea by real-time quantitative PCR (qPCR).

DNA extracts from spore trap samples were assayed in MicroAmp Fast 96-well Reaction Plate $(0.1 \mathrm{~mL})$ closed with Optical Adhesive, and by using the StepOnePlus ${ }^{\mathrm{TM}}$ Real Time PCR System (Applied Biosystems, Life Science, Foster City, CA, USA). $P C R$ reaction was performed in a $25 \mu$ final volume containing: $12.5 \mu \mathrm{l}$ TaqMan Universal master mix (Applied Biosystems), 300 $\mathrm{nM}$ forward primer (Eurofins MWG Operon, Ebersberg, Germany), 300nM reverse primer (Eurofins MWG Operon, USA), and $200 \mathrm{nM}$ TaqMan MGB probe (Applied Biosystems), $20 \mathrm{ng}$ genomic DNA. Each DNA sample was assayed in duplicate. Two wells, each containing $5 \mu l$ of sterile water, were used as the no-template control (NTC). Additionally, two wells containing DNA extracted from infected C. pinea pine tissue (positive control), and two wells containing DNA from healthy pine tissues (negative control - Luchi et al. 2018) were included. The $\mathrm{PCR}$ protocol was $50{ }^{\circ} \mathrm{C}(2$ min), $95{ }^{\circ} \mathrm{C}(10 \mathrm{~min}), 50 \mathrm{cycles}$ of $95^{\circ} \mathrm{C}(30$ $\mathrm{s})$, and $60^{\circ} \mathrm{C}(1 \mathrm{~min})$. Results were analyzed by using a SDS 1.9 Sequence Detection System (Applied Biosystems) after manual adjustment of the baseline and fluorescence threshold. The standard curve for the absolute quantification of $C$. pinea DNA was generated with 5 -fold serial dilutions (ranging from $25 \mathrm{ng} /$ tube to $40 \mathrm{pg} /$ tube) of known concentration of DNA of C. pinea (strain IT1, IPSP-CNR collection - Luchi et al. 2018). The amount of fungal DNA from spore trap samples was expressed as $\mathrm{pg}$ DNA C. pinea / $\mu \mathrm{g}$ of total DNA extracted.

\section{Data analysis}

Differences in C. pinea DNA quantity among different spore traps and sampling periods were tested by the analysis of variance (ANOVA) followed by Tukey's HSD post-hoc test.

Influence of climatic conditions on the occurrence of $C$. pinea inoculum was evaluated by the Random Forest algorithm utilizing conditional inference trees as base learners provided in the "party" package. Variable selection was done by the permutation-based attribute selection algorithm provided in the "Boruta" package. The conditional computation of variable importance accounting for correlated predictors implemented in the "party" package was used as a function to obtain feature importance. The importance of variables that were deemed important by the selection algorithm was then expressed by means of permutation-based mean decrease in accuracy (\%IncMSE) using the function "varimp", which calculates the increase in mean squared error (MSE) of predictions when the considered variable is permuted by random shuffling.

The set of predictors that were used as input for the feature importance procedure included values of mean daily temper- ature, relative humidity, leaf wetness and daily precipitation during the sampling day and every particular day of 40 days before the sampling.

All analyses were carried out by using the $R$ software ( $R$ Development Core Team 2008).

\section{Results and discussion}

\section{Occurrence of the air inoculum of $C$.}

pinea

Our study shows that $C$. pinea inoculum is present in aerobiological samples collected in a $P$. radiata plantation from May to November 2016 (throughout the entire sampling period). No significant differences ( $p$ $=0.07$ ) of C. pinea DNA collected among the traps placed in three different spots (A, $B, C)$ were observed. A continuous C. pinea inoculum production has been recorded over the whole sampling period (May-November). Despite no significant differences $(p=0.824)$ were observed among different months, three outstanding peaks of spore production were recorded (mid-June, early August and late October - Fig. 3).

Although C. pinea triggered damages on $P$. strobus in the 1930 s and some epidemiological studies were conducted in North America (Ray 1936, McCormack 1936), it has arisen scientific attention only in 2009 as a result of unexpected serious damages on $P$. strobus forests throughout several north-eastern US states (Munck et al. 2015, 2016). In Europe, it is even less studied since it was traditionally pointed as a secondary pathogen (Delatour 1969) related to stressed trees in poor plantations ( $\mathrm{Ca}$ pretti 1980). C. pinea has been reported in

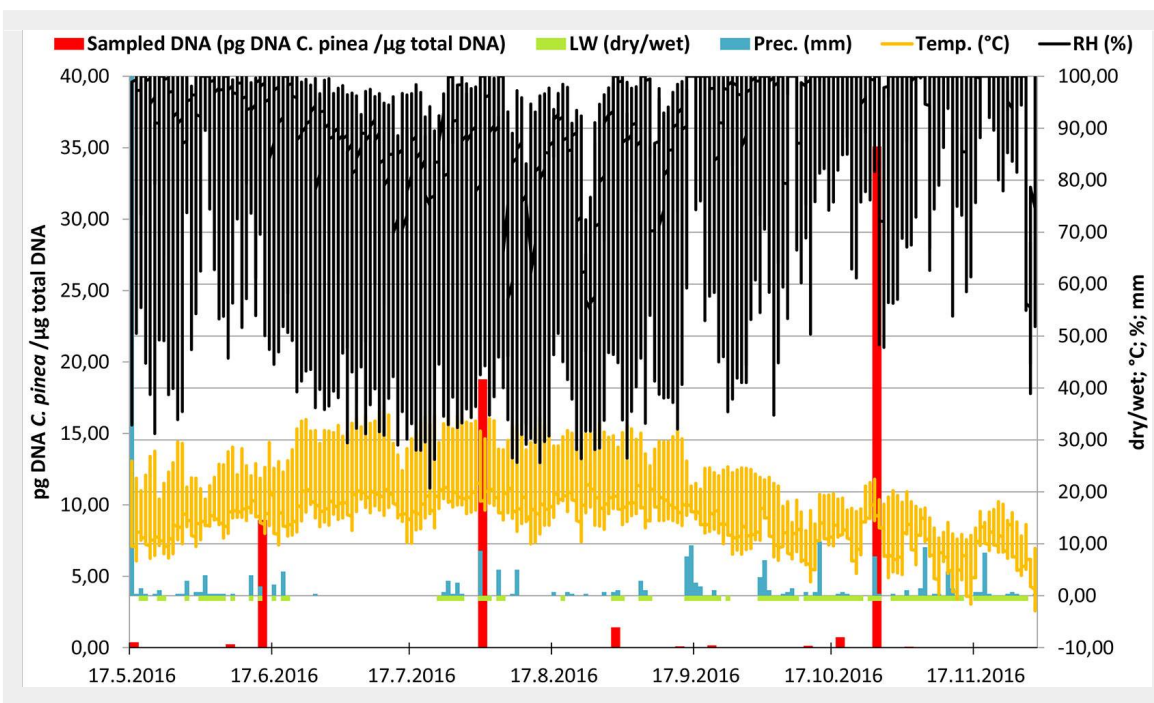

Fig. 3 - Representation of the meteorological variables in relation with the amount of airborne inoculum of $C$. pinea detected over the whole sampling period. The $x$-axis shows the progress of time. Left $y$-axis displays the template DNA quantity (pg) detected in $1 \mu \mathrm{g}$ of total extracted DNA in a logarithmic scale and reflects the amount of C. pinea inoculum trapped by the rotating arm spore trap (red columns). Daily range of precipitation ("Prec.": light blue bars, mm per day), temperature ("Temp.": orange line, ${ }^{\circ} \mathrm{C}$ ), leaf wetness ("LW": green line, scaleless; 1 = dry, $0=$ absolutely wet) and relative humidity ("RH", black line, \%) are shown on an average daily basis and scaled by the right $y$-axis. 


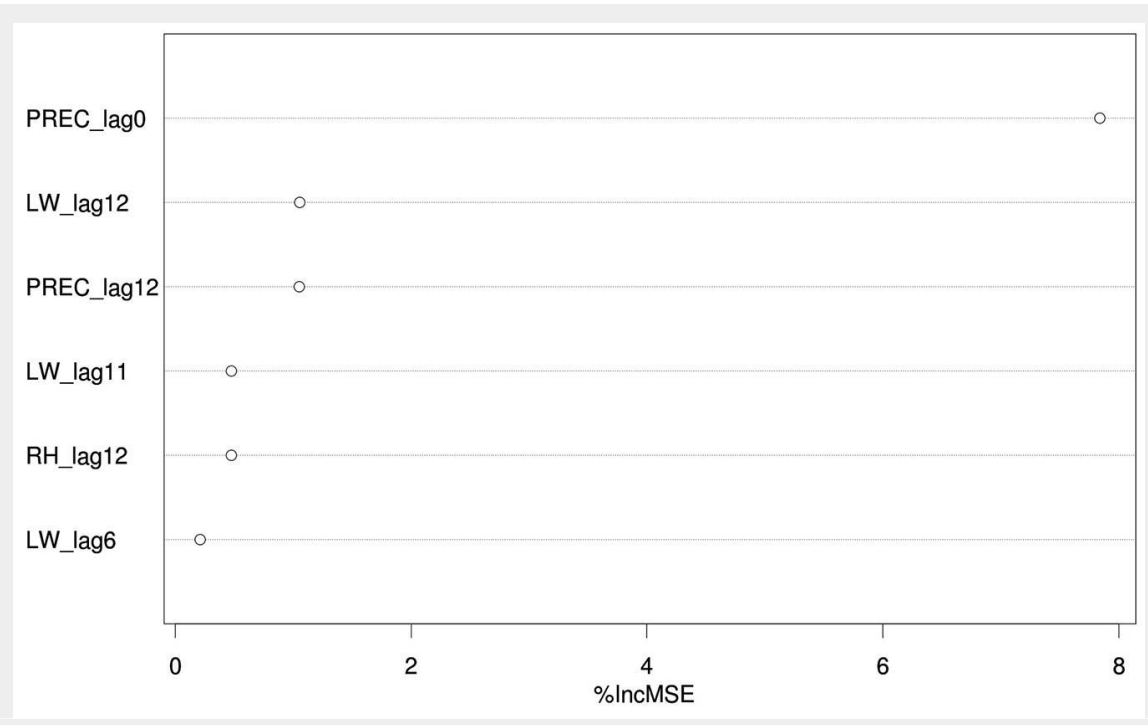

Fig. 4 - Importance (\%incMSE, permutation-based mean decrease in accuracy derived from the Random Forest algorithm) of predictors significantly accounting for the amount of airborne C. pinea spores. (PREC): precipitation (mm); (LW): leaf wetness (1=dry; $0=w e t) ;(R H)$ : relative humidity $(\%) ;(\operatorname{lagX})$ : $X^{\text {th }}$ days before sampling.

Italy since several years as the causal agent of necrosis and cankers on stems and branches on $P$. pinea, $P$. nigra and $P$. radiata (Capretti 1978, 1980, Luchi et al. 2015). A possible reason for the lack of knowledge on this pathogen is that the identification of Caliciopsis canker symptoms become more challenging as tree size increases (Munck et al. 2015, 2016). Moreover, C. pinea symptoms, such as pitching blackened, rough, resinosis and sunken bark, are similar to (and may be confused with) those caused by other important pine pathogens like Fusarium circinatum, Diplodia pinea or Diplodia scrobiculata. The capabil- ity of C. pinea to play a combined role in fungal infections on pines has been observed in 2006 on $P$. strobus trees in Bath County, VA (USA), where C. pinea was isolated together with $D$. scrobiculata from cankers and lesions of branches and stems (Cram et al. 2009). Likewise, it was collected in 2010 from a $P$. radiata sample in Spain, where both $C$. pinea and $F$. circinatum occurred on the same stem (Capretti et al. 2013). However, in our study F. circinatum was never detected from any of the conspicuous tissue explants made from symptomatic $P$. radiata tissues collected in the sampling area (data not shown). Con- versely, in Carcheri the characteristic fruiting bodies of the $C$. pinea were observed on small cankers on primary and secondary branches of $P$. nigra twigs affected by $D$. pinea (Aglietti 2015).

\section{Influence of climatic conditions on the occurrence of $C$. pinea}

The load of $C$. pinea spores in the air proved to be mostly influenced by precipitation during the sampling day and, to a lesser extent, by the amount of precipitation, leaf wetness and relative humidity of the $12^{\text {th }}$ day before sampling (i.e., spore trapping), leaf wetness of the $11^{\text {th }}$ day before and relative humidity of the $6^{\text {th }}$ day before. The importance of these variables (i.e., permutation-based mean decrease in accuracy) is shown in decreasing order in Fig. 4. All other variables were deemed not important by the algorithm used. Partial dependence plots, i.e., the dependence of c. pinea DNA amount on the significant attributes accounting for all other tested features, are displayed in Fig. 5. These results may be explained by considering the chain of events in terms of climatic conditions, fructification and sporulation. Indeed, climatic conditions may influence the formation of fruiting bodies, which has a direct impact on the number of spores produced, but they also affect sporulation, which may take place several days after the formation of fruiting bodies. This can explain the significant effect of both lagged (11-12 days before sampling) and non-lagged (like PREC_lago) climatic variables on the Caliciopsis pinea air inoculum observed in this study.

Other studies have pointed out the influence of precipitations on the inoculum occurrence of other forest pathogens, such

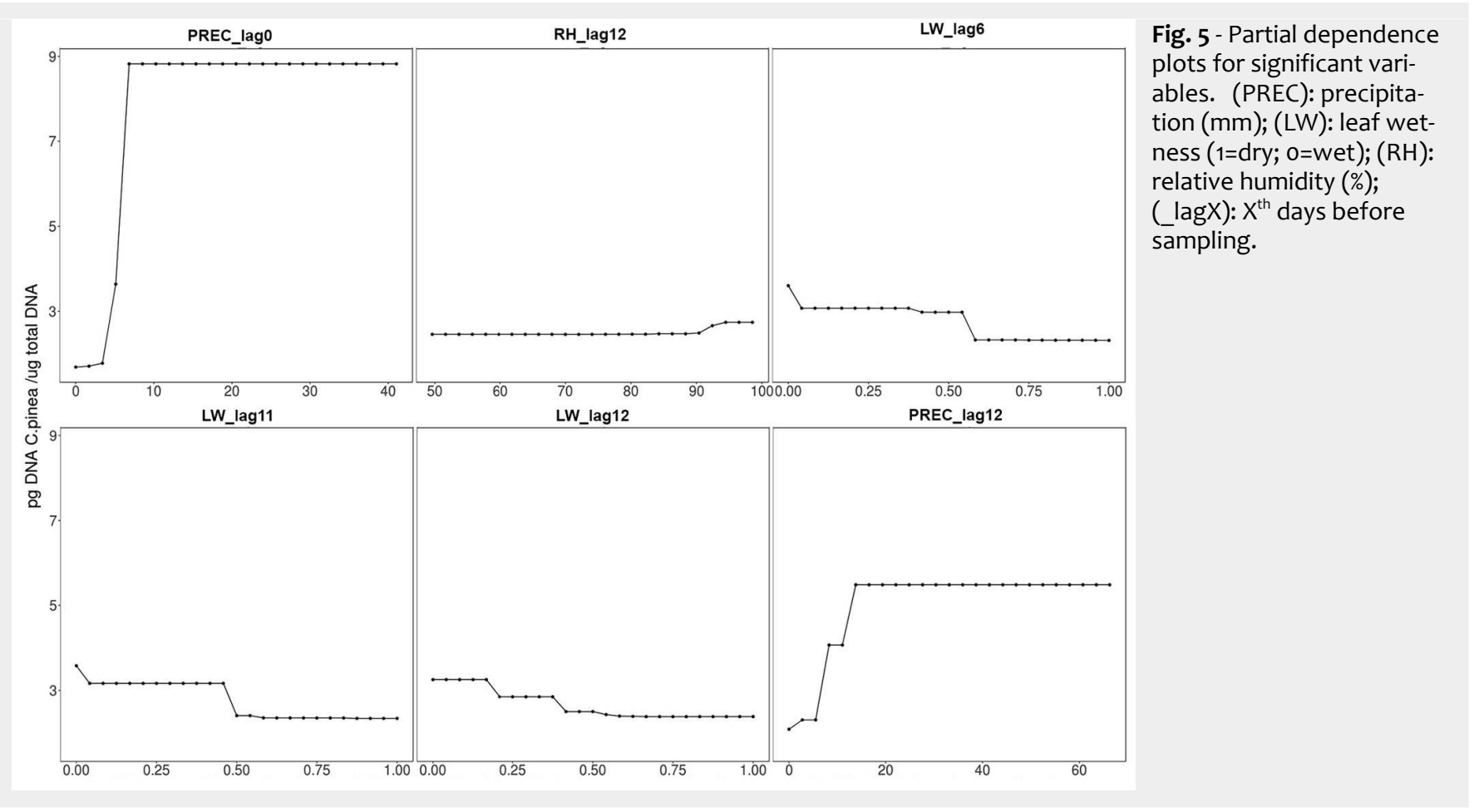


as F. circinatum (Garbelotto et al. 2008), Dothistroma septosporum (Woods et al. 2016) and Hymenoscyphus fraxineus (Cermáková et al. 2017, Dvorák et al. 2015). In the latter case, a significantly higher concentration of spores was detected in wetter than in drier localities in the Czech Republic (Cermáková et al. 2017) and the highest correlation was found between relative humidity and $H$. fraxineus air inoculum records with an approximately 13-day lag (Cermáková et al. 2017, Dvorák et al. 2015). In the present study the highest correlation $(75.96 \%)$ of $C$. pinea air inoculum was found with the relative humidity recorded 11 days before sampling.

Efficiency of rotating arm spore traps and $q P C R$ for the detection of C. pinea

The rotating arm spore traps combined with QPCR assay allowed an efficient and suitable method for early detection of this pathogen showing an extreme sensitivity up to $7.74 \times 10^{-4} \mathrm{pg}$ DNA C. pinea / $\mu$ g of total DNA extracted on 11-12 ${ }^{\mathrm{TH}}$ July, 2016 (Fig. 3). This type of spore trap has been previously utilized for the detection and quantification of the air inoculum of other important forest pathogens, such as $\mathrm{H}$. fraxineus in Belgium (Chandelier et al. 2014) and the Czech Republic (Dvorák et al. 2017), and more recently for the detection of $F$. circinatum in a plantation of $P$. radiata in Galicia, Spain (Dvorák et al. 2017). Using the Noll's equation (Noll 1970), ROTTRAP 120 was calculated to be almost $100 \%$ efficient for particles of spherical diameter of at least $7.18 \mu \mathrm{m}$ (Dvorák et al. 2017). The chiefly ellipsoidal ascospores of $C$. pinea are 5-6 × 3-3.5 $\mu \mathrm{m}$ (Fitzpatrick 1942, Lanier 1965), and the spermatia 2.5-3.5 $\mu \mathrm{m}$ in length. Regarding the theoretical calculation of Noll (1970), particles of such size are trapped by ROTTRAP 120 with the efficiency of $50 \%$ and $13 \%$, respectively. Consequently, the detected inoculum of $C$. pinea might be strongly underestimated and the actual air-borne spores' amount might be higher. The $C$. pinea inoculum was collected in 25 out of the 29 sampling days, demonstrating that the inoculum production of this pathogen covers a large part of the vegetative season.

\section{Conclusions}

The efficiency and suitability of rotating arm spore traps combined with the sensitivity of qPCR allowed the detection of $C$. pinea inoculum in the pine stand during the sampling period. The results here obtained improve our understanding of $C$. pinea epidemiology showing that the period of 12 days before the spore occurrence, which is influenced by higher relative humidity and precipitations, may enhance the fruiting body development. Later, immediate release of spores in mature fruiting bodies is triggered by rain. This approach could be applied for an efficient and effective management and control measures against this pathogen in pinewood stands.

\section{Acknowledgements}

We are thankful to the COST Action FP1406 "Strategies for management of Giberella circinata in greenhouses and forests" (PINESTRENGTH) for the support of a Short Scientific Mission "STSM" of Aneta Bacova at the IPSP-CNR (Sesto Fiorentino, Italy) during September 2016. The study was financed by the project LD15046: "Detection and biology of Gibberella circinataessentials for early warning and management strategies in the Czech Republic" (Ministry of Education, Youth and Sports of the (zech Republic). The authors wish to thank Francesco Pecori and Paola Bartolini for their help in field sampling and lab assistance.

\section{Author contributions}

$L B, M D$ and NL conceived of the study; $A B, A L P, N L, M D$ and $L B$ performed the experiments; TK and $L B$ analysed the data; LB, MD, AS and NL wrote the manuscript.

\section{References}

Aglietti C (2015). Indagini sui disseccamenti del Pinus radiata in Toscana causati da Caliciopsis pinea [Dieback of Pinus radiata in Tuscany caused by Caliciopsis pinea]. Degree in Forestry and Environmental Science, University of Florence, Italy, pp. 34. [in Italian]

Brittain I, Selby K, Taylor M, Mumford R (2013). Detection of plant pathogen spores of economic significance on pollen trap slides. Journal of Phytopathology 161: 855-858. - doi: 10.1111 /jph.12129

Capretti P (1978). Caliciopsis pinea Peck parassita di Pinus pinaster e Pinus insignis [Caliciopsis pinea Peck parasite of Pinus pinaster and Pinus insignis]. Phytopathologia Mediterranea 17: 101104. [in Italian]

Capretti P (1980). Pinus nigra var. austriaca, nuovo ospite di Caliciopsis pinea Peck [Pinus nigra var. austriaca, a new host for Caliciopsis pinea Peck]. Informatore Fitopatologico 5: 19-21. [in Italian]

Capretti P, Luchi N, Migliorini D (2013). Occurrence of Caliciopsis pinea Peck on pine: interactions with other fungal pathogens. In: Proceedings of the IUFRO meeting WP 7.02.02 "Foliage, shoot and stem diseases of forest trees". Brno (Czech Republic) 20-25 May 2013. Mendel University. Brno, Czech Republic pp. 33.

Cermáková V, Kudláček T, Rotková G, Rozsypálek J, Botella L (2017). Hymenoscyphus fraxineus mitovirus 1 naturally disperses through the airborne inoculum of its host, Hymenoscyphus fraxineus, in the Czech Republic. Biocontrol Science and Technology 27: 992-1008. - doi: 10.1080/09583157.2017.1368455

Chandelier A, Helson M, Dvorák M, Gischer F (2014). Detection and quantification of airborne inoculum of Hymenoscyphus pseudoalbidus using real-time PCR assays. Plant Pathology 63: 1296-1305. - doi: 10.1111/ppa.12218

Ciancio O, Garfì V, lovino F, Menguzzato G (2006). Il pino insigne nell'arboricoltura da legno: analisi di interventi realizzati nell'Italia meridionale [Radiata pine in wood arboriculture: analysis of interventions carried out in southern Italy]. Italia Forestale e Montana 3:
217-231. [in Italian]

Cram MM, Asaro C, Edgerton T (2009). Field inoculations of Caliciopsis pinea and Diplodia scrobiculata on eastern white pine. In: Proceedings of the "Southwide Forest Disease Workshop". Greenville (SC, USA) 29 June-2 July 2009. USDA Forest Service, Forest Health and Protection, Asheville, NC, USA, pp. 13.

Delatour C (1969). Contribution à l'étude du Caliciopsis pinea Peck: résultats complémentaires d'inoculations artificielles [Contribution to the study of Caliciopsis pinea Peck: complementary results of artificial inoculations]. Annales des Sciences Forestières 26: 285-295. - doi: 10.1051/ forest/19690205

Dvorák M, Rotková G, Botella L (2015). Detection of airborne inoculum of Hymenoscyphus fraxineus and $\mathrm{H}$. albidus during seasonal fluctuations associated with absence of apothecia. Forests 7: 1. - doi: 10.3390/f7010001

Dvorák M, Janoš P, Botella L, Rotková G, Zas R (2017). Spore dispersal patterns of Fusarium circinatum on an infected Monterey pine forest in north-western Spain. Forests 8: 432. - doi: 10.33 90/f8110432

Fitzpatrick HM (1942). Revisionary studies in the Coryneliaceae. Mycologia 34: 464-488. - doi: 10.1080/00275514.1942.12020916

Funk A (1963). Studies in the genus Caliciopsis. Canadian Journal of Botany 41: 503-543. - doi: 10.1139/b63-044

Funk A (1964). Extensions of the host ranges and distribution of Caliciopsis species on western conifers. Plant Disease Reporter 48: 677678.

Garbelotto M, Smith T, Schweigkofler W (2008). Variation in rates of spore deposition of Fusarium circinatum, the causal agent of pine pitch canker, over a 12-month-period at two locations in northern California. Phytopathology 98: 137-143. - doi: 10.1094/PHYTO-98-1-0137

LaFlamme G (2004). Rough bark diseases caused by Caliciopsis spp. In: Proceedings of the IUFRO meeting WP 7.02.02 "Foliage, shoot and stem diseases of forest trees". Corvallis (Oregon, USA) 13-19 June 2004, pp. 36.

Lanier PL (1965). Note sur une espéce cryptogamique nouvelle pour la France sur différents pins dont le pin maritime des Landes [Note on a new cryptogamic species for France on different pines including the Landes maritime pine]. Revue Forestière Française 1: 34-41. - doi: 10.426 7/2042/24685

Lavery PB, Mead DJ (1998). Pinus radiata: a narrow endemic from North America takes on the world. In: "Ecology and Biogeography of Pinus” (Richardson DM ed). Cambridge University Press, Cambridge, UK, pp. 432-449.

Luchi N, Capretti P, Migliorini D, Santini A (2015). Caliciopsis canker: a damaging disease on plantations in Italy. In: Proceedings of the Joint IUFRO 7.02.02 "Foliage, shoot and stem diseases of forest trees" and 7.03.04 "Diseases and insects in forest nurseries" meetings. Uppsala (Sweden) 7-12 June 2015. Swedish University of Agricultural Sciences, Uppsala, Sweden, pp. 21.

Luchi N, Bartolini P, Pepori AL, loos R, Santini A (2018). Duplex real-time PCR assay for the simultaneous detection of Caliciopsis pinea and Fusarium circinatum in pine samples. Applied 
Microbiology and Biotechnology 102: 7135-7146. - doi: 10.1007/s00253-018-9184-1

McCormack HW (1936). The morphology and development of Caliciopsis pinea. Mycologia 28: 188-196. - doi: 10.1080/00275514.1936.12017128 McDonald PM, Laacke R (1990). Pinus radiata D. Don, Pinaceae, Pine Family. In: "Silvics of North America, vol. 1. Conifers" (Burns RM, Honkala B eds). Agriculture Handbook 654, USDA Forest Service, Washington, Dc, USA, pp. 433-441.

Munck I, Livingston W, Lombard K, Luther T, Ostrofsky W, Weimer J, Wyka S, Broders K (2015). Extent and severity of Caliciopsis canker in New England, USA: an emerging disease of eastern white pine (Pinus strobus L.). Forests 6: 43604373. - doi: $10.3390 / f 6114360$

Munck I, Luther T, Wyka S, Keirstead D, McCracken K, Ostrofsky W, Searles W, Lombard K, Allen $B$ (2016). Soil and stocking effects on Cali- ciopsis canker of Pinus strobus L. Forests 7: 269. - doi: $10.3390 / f 7110269$

Noll KE (1970). A rotary inertial impactor for sampling giant particles in the atmosphere. Atmospheric Environment 4: 9-19. - doi: 10.1016/ 0004-6981(70)90050-8

Perkins WA, Leighton PA (1957). The rotorod sampler. Second Semi-Annual Report No. CML 186, Aerosol Laboratory, Stanford University, CA, USA.

R Development Core Team (2008). R: a language and environment for statistical computing. $R$ Foundation for Statistical Computing Vienna. [online] URL: http://www.R-project.org

Ray WW (1936). Pathogenicity and cultural experiments with Caliciopsis pinea. Mycologia 28: 201-208. - doi: 10.1080/00275514.1936.12017130 Rehm H (1896). Caliceae. Rabenhorst's Kryptogamen Flora 3: 382-414.
Santini A, Ghelardini L (2015). Plant pathogen evolution and climate change. Series "Perspectives in Agriculture, Veterinary Science, Nutrition and Natural Resources", vol. 35, CAB Reviews, Wallingford, UK, pp. 10. - doi: 10.1079/pa vsnnr20 1510035

Weber E (2003). Invasive plant species of the world: a reference guide to environmental weeds. CAB International, Wallingford, UK, pp. 548.

Woods AJ, Martín-García J, Bulman L, Vasconcelos MW, Boberg J, La Porta N, Peredo H, Vergara G, Ahumada R, Brown A, Diez JJ (2016). Dothistroma needle blight, weather and possible climatic triggers for the disease's recent emergence. Forest Pathology 46: 443-452. - doi: 10.1111/efp. 12248 